\title{
Vocational High School Students' Habits of Mind In Physics Material Through Discovery Learning Models
}

\author{
Heni Astatin ${ }^{1}$, Tantri Mayasari ${ }^{2}$, Farida Huriawati ${ }^{3}$, Rinko $\mathrm{Oi}^{4}$ \\ Universitas PGRI Madiun, Indonesia ${ }^{1,2,3}$, Meio University, Japan $^{4}$ \\ heniastatin22@gmail.com ${ }^{1}$, tantri@unipma.ac.id ${ }^{2}$, bundanerara8@gmail.com³, \\ rinko.oi.9827@gmail.com ${ }^{4}$
}

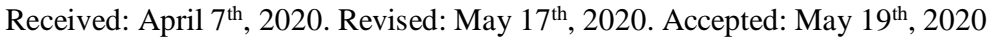

Keywords :

Habits of Mind; Discovery

Learning Model; Vocational

High School

\begin{abstract}
The Habits of Mind of SMK students must be classified as high, therefore researchers conducted research on investigating the thinking habits of SMK students by using the help of learning models based on problem solving in their own way (Discovery Learning). The method used is descriptive qualitative with a sample size of 33 students of class $X$ in SMK Madiun. Data collection uses initial and final tests. The results of the study said that students' thinking habits improved after being given questions in the form of test training, and assisted with discovery learning models. Judging from the average number of pretest and posttest worth 80.8 and 115 the $n$-gain value is 0.6 with the medium category, the value is obtained from each indicator of habits of mind thinking about thinking 1 with high category, thinking flexibly 0.9 with high category, applying past knowledge to new situation 0.7 with high category, questioning and posing problem 0.6 with medium category, creating, imagining, innovating 0.2 . Based on the N-gain value of each indicator, it can be concluded that the discovery learning model can improve students' habits of mind.
\end{abstract}

\section{INTRODUCTION}

Physical education is a science of education which is one of the branches of natural education which usually underlies the progress and development of technology which is growing rapidly. As with science that discusses natural events that can make humans able to live a life commensurate with natural law. The preservation of natural resources cannot run well if it is not based on an understanding of concepts about physics, in studying physics must apply the main key that is habits of mind.

Habits of mind.emerged through Costa [1] then continued by Marzano [2] in his book entitled "a different kind of classroom". Initially by Costa [1] made a "thought hierarchy" article in The Behavior of Intelligence [3] . Marzano revealed that habits of mind.are part of the 5 dimensions of learning, namely: (1) behavior and perception, (2) acquiring and integrating knowledge gained, (3) developing knowledge, (4) using knowledge meaningfully, (5) habits of mind. 
Habits of mind.expressed by Costa \& Kallick [4] intelligent people can be seen through how to solve problems. Below are indicators habits of mind according to Costa \& Kallick [5].

Table 1. Indicators of Habit of Mind

\begin{tabular}{|c|c|c|c|}
\hline No & Habits Of Mind & How to Train & How to Measure \\
\hline 1 & Persisting & $\begin{array}{l}\text { students are given several } \\
\text { problems }\end{array}$ & Test \\
\hline 2 & Managing impulsivity & $\begin{array}{l}\text { The teacher gives students } \\
\text { problems about physics material }\end{array}$ & Test \\
\hline 3 & $\begin{array}{l}\text { Listening with understanding and } \\
\text { empathy }\end{array}$ & $\begin{array}{l}\text { The teacher gives demonstrations } \\
\text { to students }\end{array}$ & Trial \\
\hline 4 & Thinking flexibly & $\begin{array}{l}\text { The teacher gives students } \\
\text { problems about physics material }\end{array}$ & Test \\
\hline 5 & Metacognition & $\begin{array}{l}\text { students are given several } \\
\text { problems }\end{array}$ & Test \\
\hline 6 & Striving for accuracy & $\begin{array}{l}\text { The teacher gives demonstrations } \\
\text { to students }\end{array}$ & Trial \\
\hline 7 & Questioning and problem posing & $\begin{array}{l}\text { students are given several } \\
\text { problems }\end{array}$ & Test \\
\hline 8 & $\begin{array}{l}\text { Applying past knowledge to new } \\
\text { situations }\end{array}$ & $\begin{array}{l}\text { students are given several } \\
\text { problems }\end{array}$ & Test \\
\hline 9 & $\begin{array}{l}\text { Thinking and communicating with } \\
\text { clarity and precition }\end{array}$ & Educators do demonstrations & Trial \\
\hline 10 & Gathering data through all sense & Educators do demonstrations & Trial \\
\hline 11 & Creating, imagining and innovating & $\begin{array}{l}\text { students are given several } \\
\text { problems }\end{array}$ & Test \\
\hline 12 & $\begin{array}{l}\text { Responding with wonderment and } \\
\text { awe }\end{array}$ & Educators do demonstrations & Trial \\
\hline 13 & Taking responsible risk & Educators hold demonstrations & Trial \\
\hline 14 & Finding humor & Educators do demonstrations & Trial \\
\hline 15 & Thinking interdependently & The teacher does a demonstration & Trial \\
\hline 16 & $\begin{array}{l}\text { Remaining open to continuous } \\
\text { learning }\end{array}$ & The teacher does a demonstration & Trial \\
\hline
\end{tabular}

Marita revealed that the habits of mind is a skill possessed by someone who can bring up intelligence if used by facing existing problems [6]. So, the habits of mind is a habit of someone who leads to a high ability, finally someone can act productively, so that the brain can work together in solving various physical problems in the matter of rotational dynamics. The habit of mind is very important for everyone, especially for students, because when students have high habits of mind, students will have the opportunity to solve various problems easily using their own way. Students' habits of mind will reach the highest level if students start to get used to thinking by solving exact sciences problems such as 
physics, physics becomes the main factor to raise the level of habits of mind because physics science is quite difficult for students. Students who are emphasized in the completion of physics, then students' habits of mind will be high. Based on that, physics can be used as a material to shape students' habits of mind. Researchers are able to conclude physics can be used as material to elevate students' habits of mind, because researchers are at the college level majoring in physics. Physics is the main factor to raise the level of habits of mind because physics is quite difficult for students. Students who are emphasized in the completion of physics, then students' thinking habits will be high. Based on that, physics can be used as a material to shape students' habits of mind. Researchers are able to conclude physics can be used as material to elevate students' habits of mind, because researchers are at the college level majoring in physics. Physics is the main factor to raise the level of habits of mind because physics is quite difficult for students. Students who are emphasized in the completion of physics, then students' habits of mind will be high. Based on that, physics can be used as a material to shape students' habits of mind. Researchers are able to conclude physics can be used as material to elevate students' habits of mind, because researchers are at the college level majoring in physics.

According to Costa \& Kallick, the habits of mind, namely the physical attributes of the intelligence of students in gaining knowledge and knowing how to practice through learning [5]. Meanwhile, according to Marzano et al [7] and Costa \& Kallick [5], the habits of mind is to educate children in developing their own potential. Then Sriyati revealed that the habits of mind helps students in carrying out self regulation in learning and obtaining social relations [8]. So Habits of mind is important for all students, because it can make students become aware of the various problems encountered, be able to solve various problems, be able to solve problems quickly using their own ways and make students tend to form certain intellectual behavior patterns.

But in real conditions, schools that really invite students to get used to thinking don't yet exist. So from that students become a side effect, students' thinking becomes relatively low, the activeness of students has not yet been formed, in solving problems with lessons takes quite a long time. These problems must be solved by replacing the learning model which is entirely focused on the students, so that students feel happy and enjoy the existing learning. When students feel happy, indirectly their confidence to be active will be formed. Learning model that is able to help students solve problems is discovery learning.

Discovery Learning is a learning theory that can be used as a guide to students' practice in solving problems in their own way. Discovery Learning has advantages as follows: encouragement of students to think for themselves, students practice utilizing work resources, students understand the concept of material [9]. Therefore the Discovery Learning model is able to change students from passive to active. In addition to using the Discovery Learning model to make students active and to get used to thinking by giving questions in the form of test training. This can be seen through the Rohim \& Susanto's opinion which says that Discovery Learning can give students opportunities to be more active [10].With the training questions concerning the characteristics of thinking habits, then the mindset of students will become increasingly high and students will be able and responsive to problems related to physical material. Based on this, it can be concluded that discovery learning is suitable for increasing the level habits of mind.

Supporting theory in conducting research is the data from research by Rahzianta \& Hidayat which states that students' low thinking in thinking can lead to a high level of confidence in success in tests [11]. Through this theory, researchers conducted a study of the habits of mind students of class X vocational school physics materials. This study aims to investigate how the habits of mind SMK grade X students in physics material. The reason for this research using class X is because class X Vocational High School in Madiun already has the potential in understanding the concepts of physics materials and the ability to solve problems in physics, in addition to solving problems at school, vocational students are also able to solve problems outside the school.

\section{METHOD}




\section{Place and time of research}

This research at SMK Gamaliel Madiun, located on Jl. Slamet Riyadi No.48, Kanigoro, Kec. Kartoharjo, Madiun City, East Java 63118. The study was conducted in October.

\section{Research methods}

The research method is a qualitative descriptive method. Qualitative descriptive is to take data that clearly illustrates what actually happened [12]. The data obtained in this research is through pretest and posttest activities. Research that uses qualitative descriptive is taking data where the researcher becomes the instrument answer, the data collection is carried out in combination and the data analyzed has inductive nature [13].

\section{Research subject}

The subject of research is grade X students of SMK in Madiun. The research technique uses purposive sampling with the meaning that the researcher determines taking a sample with the determination of the same characteristics as the objective, so that the research problem can be answered.

\section{Procedure for conducting research}

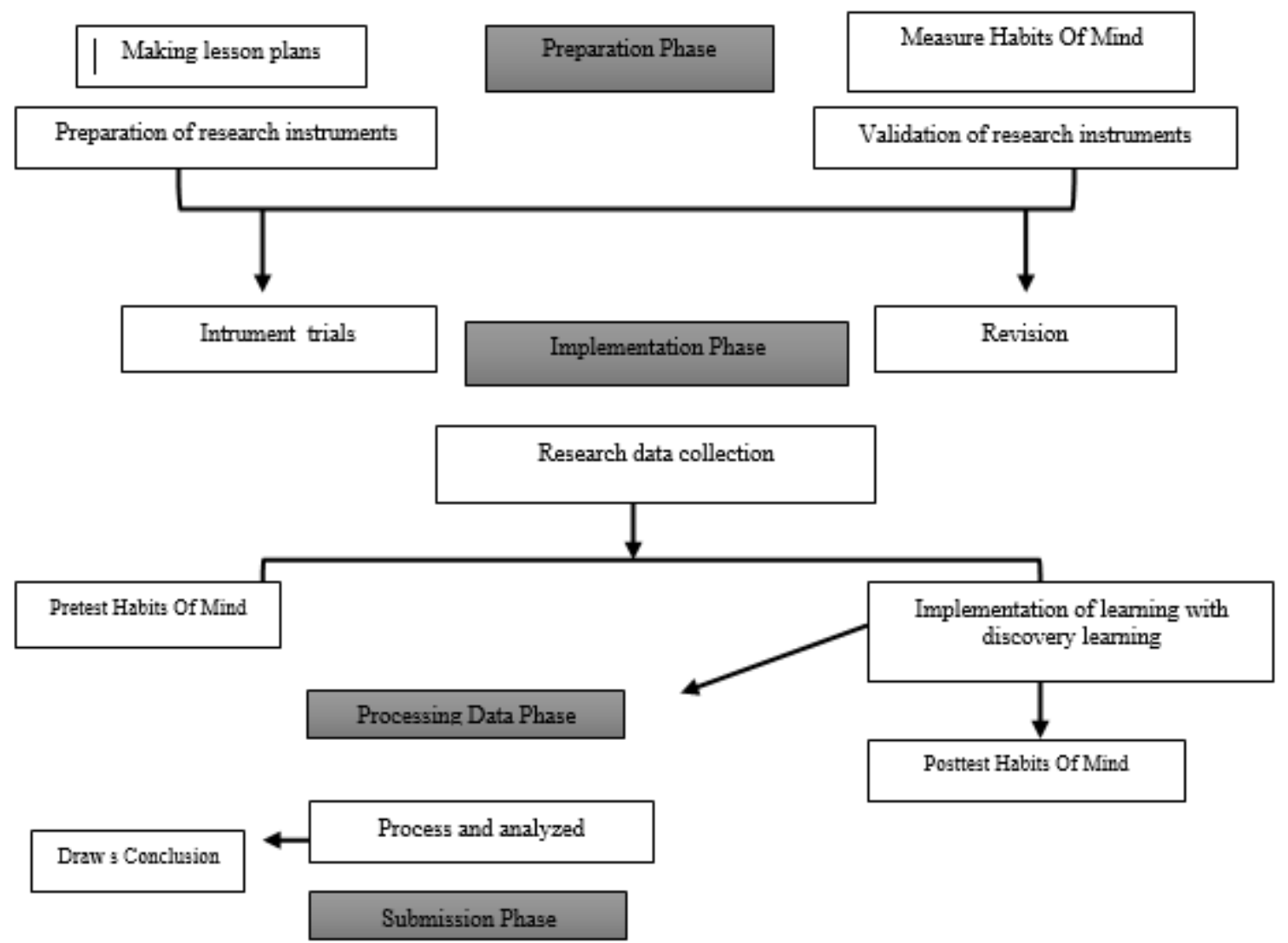

Fig 1. Research implementation stage

\section{Instruments and Data Collection Techniques}

This research instrument in the form of a syllabus, learning implementation plan, and tests (Pretest and Posttest). The test instrument used was a description test and the material being tested was rotational dynamics.Tdata collection techniques in the form of post-test and pre-test with the aim to improve students' thinking habits on physics material. The test will contain 10 questions using the habits of mind indicator. This test is divided into 2 namely 5 initial questions and 5 final questions. The following test questions are used: 
Table 2. Test Habits of Mind

\begin{tabular}{|c|c|c|c|c|}
\hline No & $\begin{array}{l}\text { Habits of Mind } \\
\text { indicator }\end{array}$ & Question & Pretest & Posttest \\
\hline 1 & $\begin{array}{l}\text { Thinking about } \\
\text { thinking (Thinking } \\
\text { about thinking / } \\
\text { metacognition) }\end{array}$ & $\begin{array}{l}\text { What factors influence the moment of force? } \\
\text { What are the quantities that affect the angular } \\
\text { momentum? }\end{array}$ & $\sqrt{ }$ & $\sqrt{ }$ \\
\hline 2 & Thinking Flexible & $\begin{array}{l}\text { Budi maintains a bat that emits electromagnetic } \\
\text { waves around } 20,000 \mathrm{~Hz} \text {. The purpose of bats is } \\
\text { to produce waves of that size so that they cannot } \\
\text { crash into objects that are around them. Budi } \\
\text { used to keep bats in a ball-shaped box with a } \\
\text { mass and radius of about } 5 \mathrm{~kg} \text { and } 5 \mathrm{~m} \text {. From } \\
\text { this event determine the angular momentum? } \\
\text { Budi maintains a bat that emits around } 5,000 \mathrm{~Hz} \\
\text { of electromagnetic waves. The purpose of bats } \\
\text { is to produce waves of that size so that they } \\
\text { cannot crash into objects that are around them. } \\
\text { Budi used to keep bats in ball-shaped boxes } \\
\text { with a mass and radius of about } 2 \mathrm{~kg} \text { and } 7 \mathrm{~m} \text {. } \\
\text { From this event determine the angular } \\
\text { momentum? }\end{array}$ & $\sqrt{ }$ & $\sqrt{ }$ \\
\hline 3 & $\begin{array}{l}\text { Questioning and } \\
\text { finding problem } \\
\text { solving } \\
\text { (Questioning and } \\
\text { posing problems) }\end{array}$ & $\stackrel{D_{\text {kasar }}}{\longleftarrow}$ & $\sqrt{ }$ & \\
\hline
\end{tabular}

Ridho climbed a homogeneous ladder leaning against a slippery vertical wall. The weight of the ladder is $300 \mathrm{~N}$ and the weight of Ridho is 700 N. If Ridho goes up as far as $3 \mathrm{~m}$ before the stairs slip. What is the coefficient of friction between the floor and the stairs?

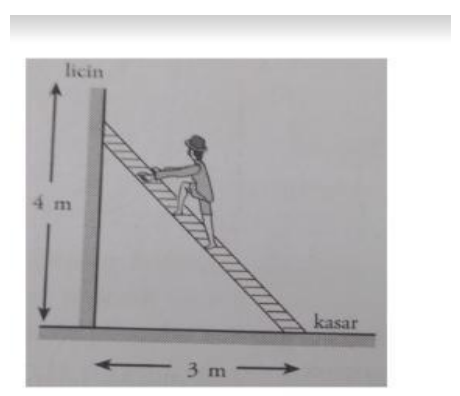

Ridho climbed a homogeneous ladder leaning against a slippery vertical wall. The weight of the ladder is $50 \mathrm{~N}$ and the weight of Ridho is $100 \mathrm{~N}$. If Ridho goes up as far as $3 \mathrm{~m}$ before the ladder slips. What is the coefficient of friction between the floor and the stairs? 


\begin{tabular}{|c|c|c|c|c|}
\hline 4 & $\begin{array}{l}\text { Use of past } \\
\text { knowledge in the } \\
\text { latest situation } \\
\text { (Applying past } \\
\text { knowledge to new } \\
\text { situation) }\end{array}$ & $\begin{array}{l}\text { information : } \\
\text { Solid cylinder } \rightarrow \text { blue } \\
\text { Cylinder ring } \rightarrow \text { green } \\
\text { Round shell } \rightarrow \text { red } \\
\text { Solid ball } \rightarrow \text { orange } \\
\text { The four objects have identical mass and the } \\
\text { fingers race in the plane while rolling without } \\
\text { slipping. If all four balls are rolled on an incline } \\
\text { at the same time, which one is the first ball to } \\
\text { reach the bottom? Tell! }\end{array}$ & $\sqrt{ }$ & $\sqrt{ }$ \\
\hline 5 & $\begin{array}{l}\text { Creating, } \\
\text { imagining, } \\
\text { innovation } \\
\text { (Creating, } \\
\text { imagining, } \\
\text { innovating }\end{array}$ & $\begin{array}{l}\text { Make a design of a high-speed spinner fidget } \\
\text { with explanation? }\end{array}$ & $\sqrt{ }$ & $\sqrt{ }$ \\
\hline
\end{tabular}

Data Analysis

Data analysis uses N-Gain to find out an increase in students habits of mind through pretest and posttest. The equation used as follow [14-15]:

$$
N-\text { Gain }=\frac{\mathrm{S}_{\text {post }}-\mathrm{S}_{\text {pre }}}{\mathrm{S}_{\text {maks }}-\mathrm{S}_{\text {pre }}}
$$

Information :

$\mathrm{S}_{\text {post }}=$ posttest score

$\mathrm{S}_{\text {pre }}=$ pretest score

$\mathrm{S}_{\max }=$ Ideal maximum score

N-Gain have a score acquisition category [16] to find out the habits of thinking. Habits of mind has a high level if $\mathrm{N}$-Gain $>0.7$, if the habit of thinking is medium if the value of $\mathrm{N}$-Gain is around $0.3<\mathrm{g}$ $<0.7$. While the lowest $\mathrm{N}-\mathrm{Gain}$ value is if $\mathrm{G}<0.3$.

\section{RESULTS AND DISCUSSIONS}

Based on the research results obtained data habits of mind of vocational students in the City of Madiun on the subject of rotational dynamics physics with the help of discovery learning models as follows:

Table 3. Pretest and Posttest averages

\begin{tabular}{clcc}
\hline No & \multicolumn{1}{c}{ Habits of Mind indicator } & Pretest & Posttest \\
\hline 1 & $\begin{array}{l}\text { Thinking about thinking (Thinking about } \\
\text { thinking / metacognition) }\end{array}$ & 124 & 132 \\
2 & Thinking Flexible & 66 & 129
\end{tabular}


$3 \quad$ Questioning and finding problem solving (Questioning and posing problems)

4 The use of past insight in new conditions (Applying past knowledge to new 66 situation) Creating, imagining, innovation (Creating, imagining, innovating

After obtaining a recapitulation of the results of the pretest and posttest average calculation of each indicator, then proceed to the calculation of the value of $\mathrm{N}$-gain (test of unalnalized gain). From the results of the average value in the table above it can be concluded that there is an increase in thinking habits even though only a slight increase. For more details, see the N-Gain score below:

Table 4. N-Gain Value

\begin{tabular}{clcc}
\hline No & \multicolumn{1}{c}{ Habits of Mind indicator } & N-Gain & Category \\
\hline 1 & $\begin{array}{l}\text { Thinking about thinking (Thinking } \\
\text { about thinking / metacognition) }\end{array}$ & 1 & High \\
2 & $\begin{array}{l}\text { Thinking Flexible } \\
\text { Questioning and finding problem } \\
\text { solving (Questioning and posing } \\
\text { problems) }\end{array}$ & 0.9 & $\begin{array}{c}\text { High } \\
\text { Medium }\end{array}$ \\
4 & $\begin{array}{l}\text { Use of past insights into new situations } \\
\text { (Applying past knowledge to new }\end{array}$ & 0.6 & High \\
& $\begin{array}{l}\text { situations) } \\
\text { Creating, imagining, innovation } \\
\text { (Creating, imagining, innovating }\end{array}$ & 0.2 & Low \\
\hline$\quad$ N-gain amount & $\mathbf{0 . 6}$ & Medium \\
\hline
\end{tabular}

Table 4 shows that the $\mathrm{n}$-gain ability habits of mind of each indicator as follows indicators of thinking about thinking belong to the high category with n-gain 1 , the indicator of thinking flexibly belongs to the high category with n-gain 0.9 , indicator questioning and posing problem classified in the medium category with n-gain 0.6 , the indicator applying past knowledge to new situation is classified in the high category with n-gain 0.7 , and for creating, innovating, imagining indicators it is in the low category with $\mathrm{n}$-gain 0.2. The data shows the value of n-gain habits of mind of students 0.6 in the medium category. During the learning process using discovery learning models, observers and researchers observe student activities while participating in learning with discovery learning learning models. All habits of mind indicators appear during the learning process using discovery learning models even though there is one indicator that is classified in the low category. The following explains the appearance of habits of mind indicators during the learning process using discovery learning models.

In table 4 shows the first indicator of thinking about thinking indicators, namely awareness of what is done and the consequences of actions taken. This indicator has an average of 124 for pretest and 132 for posttest with n-gain 1, which means it has a high category. This can be seen when students solve problems that contain things that affect the material discussed when using the discovery learning model. In the first category many students are able to mention the effect of a material. The second indicator of thinking flexibly is open thinking and providing solutions from various angles. This indicator has an average of 66 for the pretest and 129 for the posttest with an n-gain value of 0.9 which means it has a high category. This can be seen when students solve one problem using many equations. In this category many students are able to solve one problem in many ways. The third indicator is a questioning and posing problem indicator that is having a sense of wanting to understand. This indicator has an average of 81 for the pretest and 112 for the posttest with an n-gain of 0.6 , which means it has a medium category. This can be seen through students when working on problems that are not yet able to connect the problems with daily life and are not too capable of connecting problems with what is in their minds. In this indicator only half of the students are able to associate the problem with what is thought. The fourth 
indicator applies the indicator past knowledge to new situation with the meaning of contracting old knowledge with new knowledge. This indicator has an average of 66 for the pretest and 118 for the posttest with an n-gain of 0.7 in the sense of having a high category. This can be seen through students when working on problems using the methods that have been given in the old learning. The fifth indicator of creating, imagining, innovating is the delivery of different ideas. In this category many students are able to work on problems using knowledge that has been obtained. This indicator has an average of 67 for the pretest and 84 for the posttest with an n-gain of 0.2 in the sense of having a low category. It can be seen through students when working on problems that smell like making a tool framework.

Based on the description above, it can be said that the average value of the pretest of each indicator of habits of mind before using discovery learning, the average value is still low, the low habits of students are due to the ability of students' habits of mind have not been optimally explored and the lack of stimulus provided by the teacher, whereas after using discovery learning models the average value has increased. Discovery learning model is a model that makes students active and makes students able to solve problems in their own way. The syntax of discovery learning models that help improve students' habits of mind is the fifth syntax and the sixth syntax. The fifth syntax is that students are encouraged to carry out experimental activities, in this experiment students do it carefully so that they can produce data according to the guidelines. The sixth syntax is analyzing the experimental data, in this syntax students learn how to solve the data that has been obtained using their own method.

The results of this study make a major contribution to the field of education, such as discovery learning models can be used by teachers as a learning model for the application of students' habits of mind. When the habits of mind of high school students automatically graduate qualified students. The quality of graduates and the quality of education in schools is formed by how the teacher provides material to students, and is formed from the use of learning models.

\section{CONCLUSION AND SUGGESTION}

From the results and discussion earlier, the conclusion can be stated that the ability of students' habits of mind have improved after discovery learning model is applied with improvement score of 0.6 in medium category.

\section{REFERENCES}

[1] Costa, A. L. (1985). Developing minds: A resource book for teaching thinking. Association for Supervision and Curriculum Development, 225 N. Washington St., Alexandria, VA 22314.

[2] Marzano, R. J. (1992). A different kind of classroom: Teaching with dimensions of learning. Association for Supervision and Curriculum Development, 1250 North Pitt Street, Alexandria, VA 22314 (ASCD stock no. 611-92107, \$15.95, plus \$2.50 handling)..

[3] Campbell, L., Campbell, B., \& Dickinson, D. (2006). Metode praktis pembelajaran: berbasis multiple intelligences. Intuisi Press.

[4] Costa, A. L., \& Kallick, B. (2012). Belajar dan Memimpin dengan 'Kebiasaan Pikiran'16 Karakteristik Penting untuk Sukses. Jakarta: PT. Indeks.

[5] Costa, A. L., \& Kallick, B. (2000). Describing 16 Habits of Mind. Habits of Mind: A Development Series. Alexandria, VA.

[6] Marita, R. A. S. (2014). Profil Habits Of Mind Siswa SMA kelas XI pada Pembelajaran Biologi Menggunakan Metode Praktikum dan Diskusi. In MATHEMATICS AND SCIENCES FORUM 2014.

[7] Marzano, R. J., Pickering, D., \& McTighe, J. (1993). Assessing Student Outcomes: Performance Assessment Using the Dimensions of Learning Model. Association for Supervision and Curriculum 
Development, 1250 N. Pitt St., Alexandria, VA 22314 (Stock Number 611-93179, \$13.95).

[8] Sriyati, S. (2011). Penerapan Asesmen Formatif Untuk Membentuk Habits of Mind Mahasiswa Biologi. Sekolah Pascasarjana UPI (Doctoral dissertation, Thesis. Tidak diterbitkan).

[9] Kurniasih, I., \& Sani, B. (2014). Perancangan Pembelajaran Prosedur Pembuatan RPP yang Sesuai Dengan Kurikulum 2013. Jakarta: Kata Pena.

[10] Rohim, F., \& Susanto, H. (2012). Penerapan model discovery terbimbing pada pembelajaran fisika untuk meningkatkan kemampuan berpikir kreatif. UPEJ Unnes Physics Education Journal, 1(1).

[11] Rahzianta, R., \& Hidayat, M. L. (2016). Pembelajaran Sains Model Service Learning Sebagai Upaya Pembentukan Habits of Mind Dan Penguasaan Keterampilan Berpikir Inventif. Unnes Science Education Journal, 5(1).

[12] Mukhtar, P. D. (2013). Metode Praktis Penelitian Deskriptif Kualitatif. Jakarta: GP Press Group.

[13] Arikunto, S. (2010). Prosedur Penelitian: Suatu Pendekatan Praktik (Edisi Revisi). Jakarta: PT Rineka Cipta. ISBN 9789800000000.

[14] Meltzer, D. E. (2002). The relationship between mathematics preparation and conceptual learning gains in physics: A possible "hidden variable" in diagnostic pretest scores. American journal of physics, 70(12): 1259-1268.

[15] Archambault, J., Burch, T., Crofton, M., \& McClure, A. (2008). The effect of developing kinematics concepts graphically prior to introducing algebraic problem solving techniques. Action Research required for the Master of Natural Science degree with concentration in physics.

[16] Hake, R. R. (1999). Analyzing change/gain scores. Unpublished.[online] URL: http://www. physics. indiana. edu/ sdi/AnalyzingChange-Gain. pdf. 